\title{
Discussion on How to Absorb Excellence from National Culture for Chinese Art Design
}

\author{
Zhenglei Dong \\ Huanghe Science and Technology College \\ Zhengzhou, China
}

\begin{abstract}
This article aims at explaining that Chinese art design shall absorb nourishment from national culture through analyzing characteristics of Chinese national culture and relationship between modern art design and national culture, in order to improve quality, perfect theory and enrich pattern of manifestation.
\end{abstract}

Keywords—art design; national culture

\section{INTRODUCTION}

Art design is indispensable component in modern art. It is a comprehensive cultural system that mixes various disciplines, mingles various cultures and covers every walk of life. It reflects the beauty of rhythm and balance in art through concrete visual images such as modeling, color and structure. Meanwhile, it integrates with various fields such as society, market, economy, technology, nation as well as religion to exert the function of serving our life.

So to speak, Chinese art design has long history and brilliant achievement. But art design with modernization significance starts from the reform and opening-up policy in the 1970 s and 1980s, so that many people think modern art design belongs to "imported goods" for China. Even the work of Chinese art and design history written by Chinese people once was labeled alternative name of "History of Chinese Arts and Crafts". Except for the reason that part of the history and noun evolve, in the final analysis, Chinese people lose confidence of their own. Then where is the confidence for rise of art design? I think it depends on the rise of national spirit. In art design, the rise of national spirit is showed as visual images such as modeling and color adopted in art design works and intrinsic culture carried by art design works. After entering the 21st century, this kind of manifestation of Chinese art design becomes increasingly outstanding. For example: the logo design of the five big state-owned commercial banks base on symbol of Chinese ancient coins as the main modeling, and symbols such as dragon, Chinese characters and the ear of wheat as auxiliary modeling; the mascot of Beijing Olympic Games in 2008 assimilate five Fuwa to cultural elements such as the five elements, five directions and five colors in traditional culture of the Chinese nation; the torch of Beijing Olympic Games uses the pattern of auspicious clouds as the texture; the new Suzhou Museum designed and constructed by architect Mr. Leoh Ming Pei uses new building technology and modern method to interpret shape and structure of traditional architecture in Suzhou. Therefore, only through absorbing nourishment from national culture can art design go to the world and remain invincible in competition. The so-called "national culture" refers to tangible and intangible cultural heritage identified by all ethnic groups in China without frontier restriction. For example, in art design, red color with high purity, stroke and structure of Chinese characters and the simultaneous use of black and white are widely considered as having strong "Chinese flavor". This is of course not the nomen of a nation. Compared with nations in other countries, it is obvious that the name of "Chinese nation" has strong cultural implications. This culture is the inexhaustible fountain for art design as well as the basis for Chinese art design to go to the world. As the culture body, art design will certainly continuously enrich and create new national culture and become important composition of diverse culture in the world.

\section{CHARACTERISTICS OF NATIONAL CULTURE IN CHINA DECIDE SHE BECOMES IMPORTANT FACTOR TO INFLUENCE ART DESIGN.}

\section{A. National Culture in China Has Inheritance}

Although the name of Chinese nation is controversial, in the category of emotion and culture, it can refer to joint name of all nationalities in China. It is more difficult to distinguish the boundary on emotion and culture. The Han nationality, principal part of Chinese nation, was called Huaxia nationality. It formed in the last phase of primitive society. It goes through more than two thousand years during Xia dynasty, Shang dynasty and Qin dynasty and lives in Central China. The minority culture has become important content in Chinese national culture. In order to win victory in international competition, art design must reflect culture of this nation on form and connotation. No matter on style and culture, Chinese contemporary art design has many contents that plagiarize western design. The behavior perspective and values carried by western art design are the results of long-term selection of culture. In western countries, the culture starting at ancient Greece and Rome is the identification of democracy and republicanism; the art and design in middle ages has profound religious color. Religious doctrine is the restriction of artistic creation and design idea; in the Renaissance Period, people took humanism as their identification and showed the confidence full of optimism for life. Chinese art design lays the roots in the soil of Chinese traditional national culture. Plagiarizing and referring to the form of western design can only be imitation on the surface. It is impossible to embody 
spiritual essence of western design. The inheritance of national culture makes art design rooted in culture have intricate "blood" relationship from ancient times to the present. When the contents of national culture and tradition provide nourishment for art design, it also needs art design to carry forward and enrich national culture, then create more "inheritable tradition" for later generations. It is the social responsibility that must be born by art design that makes national culture become visual image and material. Except for tangible cultural achievements such as architecture, painting, sculpture, tools and clothing, national culture also includes a good deal of intangible cultural achievements such as philosophic thinking, literature and art, music and dance, academic achievements as well as achievements in scientific research. These achievements can be inherited and carried forward through visualizing and materializing art design.

\section{B. Chinese National Culture Has Religious Nature}

Although the Huaxia nationality in China (namely the main force of Han nationality) doesn't produce worldwide religious faith, it forms in the warring state period. The Taoist school represented by Laozi and Zhuangzi paves the way for production of the subsequent Taoism. The thought of Taoist school and the subsequent Taoism cannot become worldwide religion. It has relationship with main ideas of the theory of Taoism and contents of Taoist doctrine. However, just as flesh and blood, the concept of "Tao" has become important characteristics of genetic gene of all nationalities in China in more than two thousand years time. The daily performance and art design creation of Chinese people subconsciously and always can show the concept of "Tao". I think the biggest contribution of Taoist thought is that it solves the problems appeared in relationship between human and nature. The art design in China shall not only embody the culture of mainstream nationalities in Central Plains. It is more improper to advocate the so-called "international style" without national characteristics.

\section{Chinese National Culture Has Characteristic of Fusion}

Different from general arts, art design is comprehensive art and not only simple combination of modeling, color and texture. China is a multinational country. The intersection and fusion of various national cultures become inexhaustible fertile soil of resources for Chinese art design. The great convergence of these cultures exerts huge effect on constituent of Chinese nation. Meanwhile, it greatly enriches Chinese national culture. As a designer, it is necessary to deeply understand the connotation of national culture, so that it can be freely applied to design creation and embody the quintessence of Chinese design culture. Thereby, it can make design become carrier of national culture. The characteristic of fusion of Chinese national culture create possibility for it.

\section{Chinese National Culture GREATly EnRICHES SPIRITUAL LANGUAGE AND PATTERN OF MANIFESTATION OF} ART DESIGN

The spiritual language of art design refers to national cultural spirit congealed in art design. Spiritual language decides the quality of art design. It is the nature of Chinese art design distinguishing from other art designs. Spiritual language is not inherent of art design but gradually penetrates in the development process of art design and shows in the form of visual works. Only through continuously enriching spiritual language of art design can we constantly improve the quality of art design. The works of a designer mainly show design idea with visual image. Therefore, many people think technological means and pattern of manifestation for art design creation are the most important. They always neglect spiritual language of art design. As the saying goes, what belongs to the nation belongs to the world. Designers shall widely and cursorily read historical and cultural tradition of this nation and understand historical origin, cultural development and folk customs of nationalities of this nation. For example, in building design, on the basis of understanding evolution of architectural style of each nationality and decoration style, designers can design works with national features. Compared with works that blindly pursue international style and the so-called advanced design in western countries, it has more spiritual language. Only these works can truly go to the world. There is no doubt that the well-known building of column type is the classic work in western architectural design. Nowadays, it goes to the world as competitive product. There is no lack of works that follow the example of it. However, it designers don't deeply understand national culture and historical tradition of ancient Greece and Rome and lack understanding for the beauty of proportion of modeling originating from ancient Greece, it is impossible for them to truly embody this kind of spiritual language in works. Similarly, the classic architecture style in China also has the phenomenon of being abused. Therefore, at present, in some places of China, we can often see Corinthian order that is randomly shortened or lengthened. The top of high-rise building is covered by a colored glaze cap. Art design belongs to interdisciplinary subject. Its theoretical system is gradually perfected in the process of continuously absorbing research achievements of other disciplines. For example, the symbol theory, chaos theory and system theory in art design theory are achievements absorbed from other disciplines. Art design doesn't have inherent core theory system of its own. Besides, it is unnecessary to establish theoretical system. Chinese national culture, especially minority culture also continuously improves theoretical system of art design. Many recognized advanced design theories are not originated from the west. Tracing our national culture, you will find those theoretical thoughts earlier afar than modern and contemporary in the west are covered with dust in articles and quotations of ancient sages. Art design involves various aspects of social life. It can be divided into three fields in general. The first is environmental art design. It designs the space for human living, including building, gardens, urban planning as well as indoor and outdoor decoration; the second is product art design. It is the design for human use, including artifacts provided for use in daily life such as tools and clothing; the third is visual communication design. It is the design for exchange of ideas and information spreading between people, including advertisement, poster and animation. There is a great diversity of patterns of manifestation of art design. But in nature, it uses visual matter image such as modeling to carry certain social functions. This characteristic decides art design must learn ability from various fields of social life and continuously 
enrich its expressive force. In our country with multiple nationalities, the cultural inheritance of architecture, painting, language, character, clothing and festivals in various nationalities provides nourishment for art design and greatly enriches pattern of manifestation of art design. In recent years, some forms with strong Chinese national characteristics such as cloud pattern, flame figure and Chinese knot are widely applied in modern art design and have achieved great success.

\section{Minority CUlture In China Plays an IMMEASURABLE ROLE IN PROMOTING THE DEVELOPMENT OF ART DESIGN}

There are 55 minorities in the big family of Chinese nation. Although these minorities have small population, on cultural dimension such as clothing, building, music, dance and behavior, for art design with visual aesthetics as pattern of manifestation, it is the soil that can provide nourishment. It mainly because minority culture is relatively weak and there are many unknown contents remained for designers to excavate and show. In terms of dress culture of minorities, there are many minorities in China. In addition, each nationality has several sub-lines. The culture of each nationality has diversified characteristics. However, the culture inside each nationality is unique and conservative. There are obvious style differences between nationalities on national finery culture. In art design, with the method of deconstruction, it can extract many symbolic elements from national finery culture. These symbolic elements can be applied to costume designing as well as other fields of art design. Ethnic elements are often introduced in modern furniture design. National customs is a popular trend of home decoration in recent years. Under the guidance of this kind of trend, patterns and decorative design with strong regional characteristics are widely applied to decorative finish of household decorations. It is worth mentioning that the design of much furniture only simply prints or engraves these auspicious patterns with national style on surface of objects. There are only similar in form without fusion of spirit. It seems to be a little far-fetched. Therefore, when designers use elements of minorities to design, they have to comprehensively understand the profound meaning of this nationality and elements used by them. They shall not make a deliberate misinterpretation out of context and take a part for the whole. There should be a correct method to apply elements of minority to modern art design. Auspicious patterns of minorities have connotations. We shall find its origin and seize essence, apply quintessence in design to reach to effect of making the finishing point. It's worth noting that when applying auspicious patterns to furniture, designers cannot neglect the comfort and ease of use of furniture. Moreover, they cannot fall into the shackles that model for beauty and decorate for decoration. They should keep ethnic characteristics of furniture as well as design excellent products that can meet people's physiological and psychological requirements. Minority culture also plays an important role in enriching the theory of modern art design. Since the turn of the century, the localization theory in art design attracts people's attention again. Because of being influenced by western design ideological trend for many years, Chinese art design pays inadequate attention to local culture, especially for minority culture, which leads to the fact that a large number of outstanding cultural elements are neglected and forgotten. Some minority cultures are close to be lost in transmission. Nowadays, a growing number of designers begin to pay close attention to these cultures and apply elements in these minority cultures to their works of art design. It carries forward national culture as well as enriches the theory of art design.

\section{CONCLUSION}

Art design is an important component of culture. In face of impact of global culture in 21st century, how to prevent our art design from losing its characteristics and losing on the big world stage without any competitiveness? We shall keep a foothold on national culture, mingle foreign culture, excavate minority culture, continuously enrich and perfect theory of art design and pattern of manifestation and create art design culture of Chinese nation.

\section{REFERENCES}

[1] Yang Xuemei. Application of Taoist Thought in Modern Indoor Design, Journal of Huangshi Institute of Technology.

[2] Ma Benhe. Zen and the Chinese Art Spirit, Heilongiiang National Series, 2009, (2).

[3] Du Yonghao. Huaxia-the Han Nationality, Chinese Nation and Chinese People, Heilongiiang National Series, 2010, (1).

[4] Liu Fusheng. Relationship between Political Power of Five Dynasties and Ten Kingdoms and Southwestern Ethnic Minorities, Journal of Sichuan University: Philosophy and Social Science Edition, 2010, (2). 